\title{
THE CYCADS OF SOUTHERN AFRICA
}

\section{INTRODUCTION}

The object of this account of the Cycads of Southern Africa is to summarize the salient information which will interest the botanically minded members of the general public. It has been prepared in conjunction with a taxonomic treatment of the species for the Flora of Southern Africa and for this reason the descriptions of individual species have been abbridged, literaturc references minimized and herbarium specimens not cited. The area concerned lies south of the Limpopo River.

Records show that keen interest in the Cycadaceae has not flagged much during the past 200 years. Sixty years ago Worsdell, writing in the Annals of Botany Vol. 20: 129 (1906), said that " no Family of Plants is exciting more interest at the present day than the Cycadaceae, and for the prime reason that they represent one of those forms of plant life which link the types of the far past with those of the present modern world ".

The family Cycadaceae, as generally accepted in the past, is represented widely in the southen hemisphere and in limited areas of the northern hemisphere. The greatest Cycad concentrations are in Mexico, central America, and Queensland in Australia. Queensland has three genera, Lepidozamia Macrozamia and Bowenia; Mexico three, Dioon, Ceratozamia and Zamia. No other region can claim more than two genera. In Southern Africa we have Stangeria and Encephalartos.

When the Cycadaceae of Southern Africa were monographed in the Flora Capensis by Hutchinson and Rattray in 1933, one species of Stangeria and 13 of Encephalartos were recognized. When Henderson contributed his results towards a "Revision of the South African species of Encephalartos" in the Journal of South African Botany in 1945 , he listed 18 described species and suggested that it would be necessary to name and describe several more, once it were possible to do some intensive field work. Most of Henderson's forecasts have proved well founded and only one completely new discovery has been recorded since his summary of 1945, and that is Encephalartos inopinus.

The other newly established species since Henderson's work are: $E$. arenarius (distinguished from E. latifrons); E. humilis (segregated from E. lanatus); E. lebomboensis (distinguished from $E$. altensteinii); E. natalensis (segregated from E. altensteinii); E. ngoyanus (segregated from E. caffer): E. princeps and E. trispinosus segregated from $E$. horridus and $E$. lehmannii; and $E$. umbeluziensis (distinguished from $E$. villosus). E. friderici-guilielmi has been reinstated and distinguished from E. cycadifolius, whereas $E$. striatus (possibly equal to $E$. villosus or E. umbeluziensis), has been excluded because of inadequate information for its certain identification with any known species.

Thus 26 species of Encephalartos and an indeterminate number of natural hybrids are dealt with in the present work. The distribution of these begins in the north with $E$. transvenosus on the Soutpansberg, and E. eugene-maraisii on the Waterberg, and extends mainly in mountainous areas of the eastern Transvaal into Natal and the southeastern Cape as far as the district of Uniondale. Here E. longifolius is the species which has penetrated furthest towards, or persisted nearest to, the south-western Cape flora. No record of the genus has come from the Orange Free State or South West Africa.

Records of species in tropical and subtropical Africa are widespread but the number is unlikely to be as many as half that for southern Africa.

In the case of the monotypic genus Stangeria, it occurs in coastal districts from Bathurst in the eastern Cape to northern Zululand near Kosi Bay. It may well be found to occur in southern Portuguese East Africa.

The accompanying map gives a guide to the limits of distribution of the family in our area. 


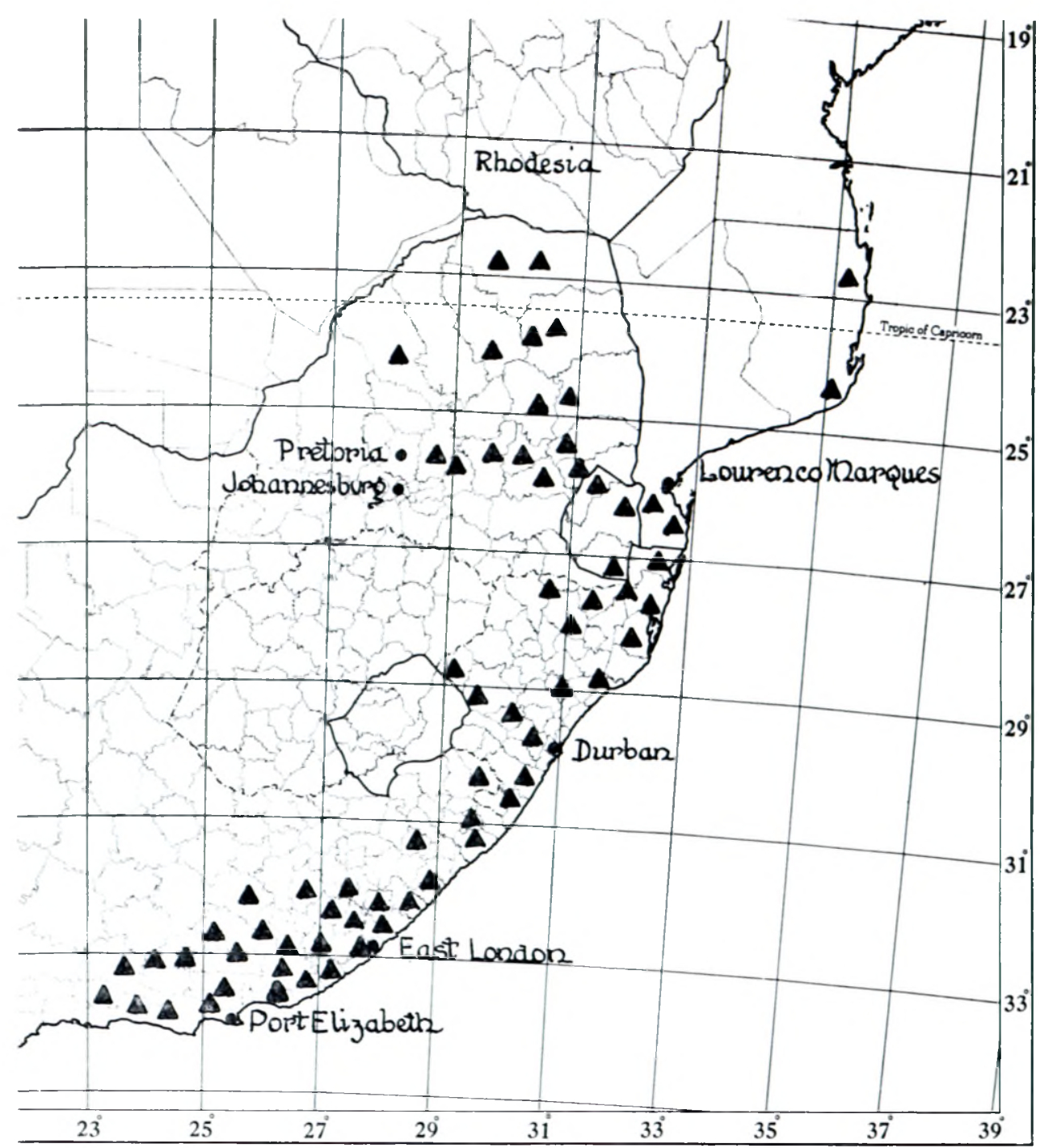

MAP: Showing distribution of family, $C y$ cadaceae, in Southern Africa.

\section{LITERATURE}

A vast amount of literature about Cycads has accumulated over the years and no attempt is made to present a list of references here. Hutchinson and Rattray give most of the references to earlier taxonomic literature in Flora Capensis 5, 2 (Suppl.) 1933. An article on economic aspects of Cycads published in Economic Botany 12, No. 3 (1958) by John W. Thieret is supported by 296 references to literature. The literature on the toxicity of Cycads is summarized by Marjorie Whiting in Economic Botany 17, No. 4 (1963) with 254 references, which gives some idea of what the preparation of a full bibliography would entail. Henderson's work has been referred to above and other works are mentioned in the pages which follow.

The present account is based very largely on field observations but there are still many problems which call for further attention and this by no means pretends to be the last word. 


\section{ACKNOWLEDGEMENTS}

As this project has gone on the number of those to whom I am indebted in one way or another, has grown beyond expectations. I thank them all.

Material and information has been received from the Directors of the following Institutions: Royal Botanic Gardens, Kew; Berlin-Dahlem Herbarium; Botanisch Museum sen Herbarium, University of Utrecht; Rijksherbarium, Leiden; Jardin Boptanique de l'Etat, Bruxelles; Institutum Botanicum, Szeged; Naturhistorisches Museum, Vienna; National Botanic Gardens, Kirstenbosch; Bolus Herbarium; Nature Conservation Dept., Transvaal Province; Penge Asbestos Mine; Parks Departments of Port Elizabeth, East London and Queenstown.

Among private people my special thanks are recorded to Mr. G. G. Smith, who has travelled several thousand miles in quest of field knowledge of our Cycads and has built up a valuable study collection in the grounds of the East London Museum, and to the late Basil Christian who accompanied him on several excursions; to the late Dr. N. R. Smuts; to Mr. V. Pringle, Mrs. N. H. James, Mr. J. A. Smit, Mr. C. Els, Mr. Louis Naude, Mr. Jimmie Hall, Mr. A. P. du Plessis, Mr. W. P. Diepraam, Mrs. Olive Hilliard, Prof. R. H. Compton, Dr. E. E. A. Gledhill, Dr. Edna Plumstead, Prof. A. W. Bayer, Miss Courtenay-Latimer, Mr. L. Renton, Mr. B. J. Huntley and Miss G. Blackbeard, also Mr. L. N. Prosser, Mr. T. Linley and Mr. A. Paton.

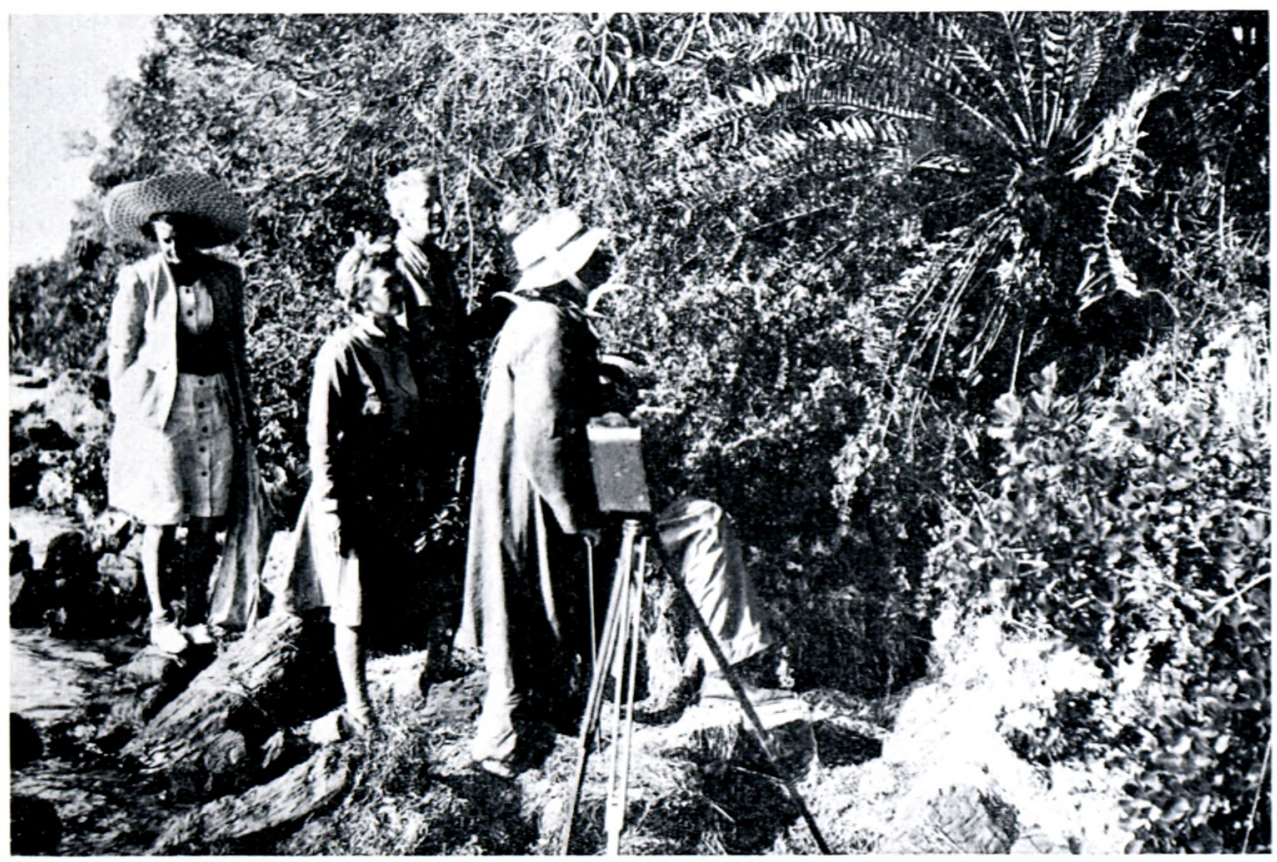

FIG. 1.-Cycad hunting: Miss Courtenay-Latimer, Miss Johns, Prof. R. H. Compton and Mr. G. G. Smith investigating possible hybrids between Encephalartos altensteinii and E. trispinosus on the west bank of the Bushmans River in the Alexandria district.

Most of my colleagues in the Botanical Research Institute have been involved to a greater or lesser degree and with apologies to those I omit by name, I must mention Dr. L. E. Codd (Chief), Miss M. Gunn (Librarian), Mrs. E. van Hoepen, Mr. M. J. Wells, Mr. R. G. Strey, Messrs H. King and J. Reyburn (photographers), Mrs. M. B. Coetzee (typist) and Miss I. C. Verdoorn, who has a fundamental knowledge of the Cycads, who has contributed several articles on the group and who is joint author with me of the taxonomic account being prepared for the Flora of Southern Africa. 


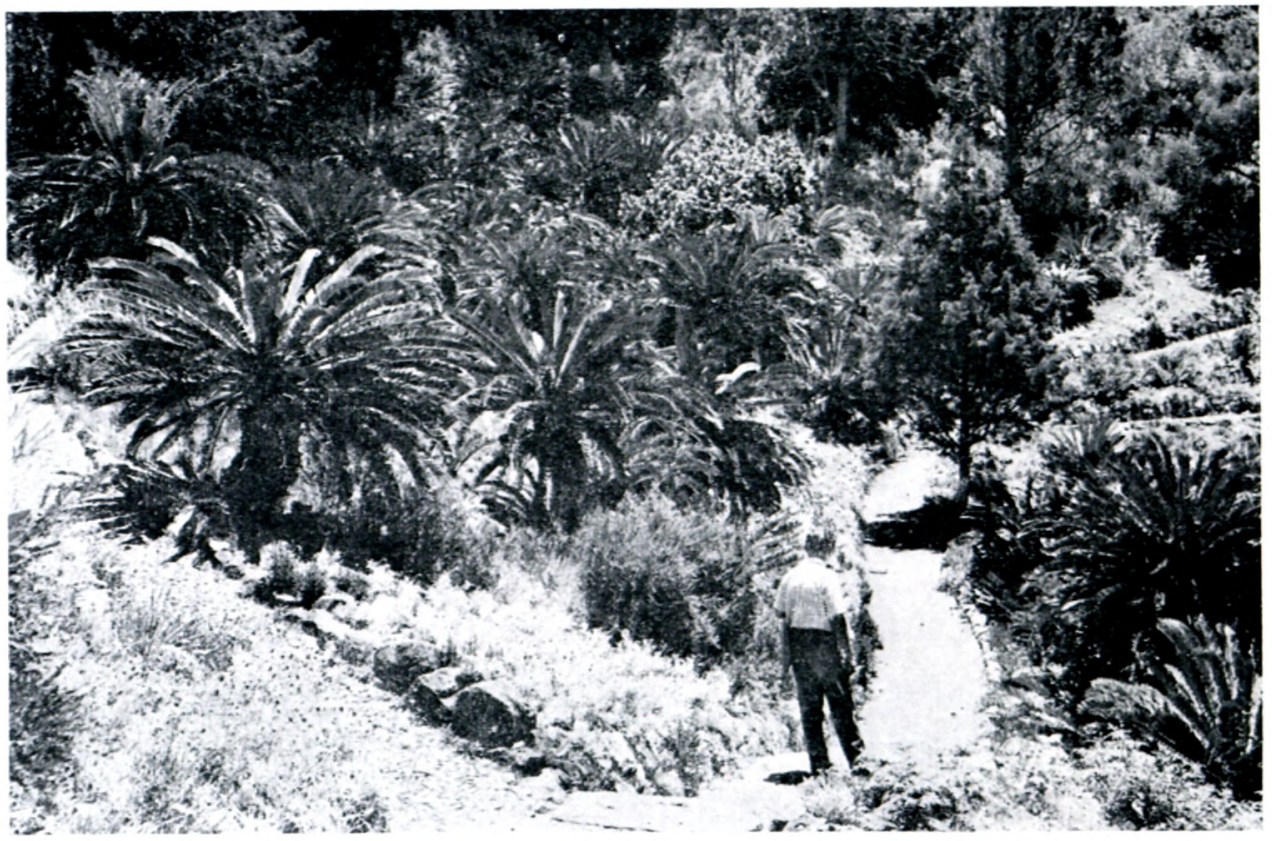

Fig. 2.-Portion of Cycad collection at the Kirstenbosch Botanic Garden, started by Pearson about 1913: by 1916 fourteen to sixteen species were represented there by approximately 500 specimens; photo taken 1948.

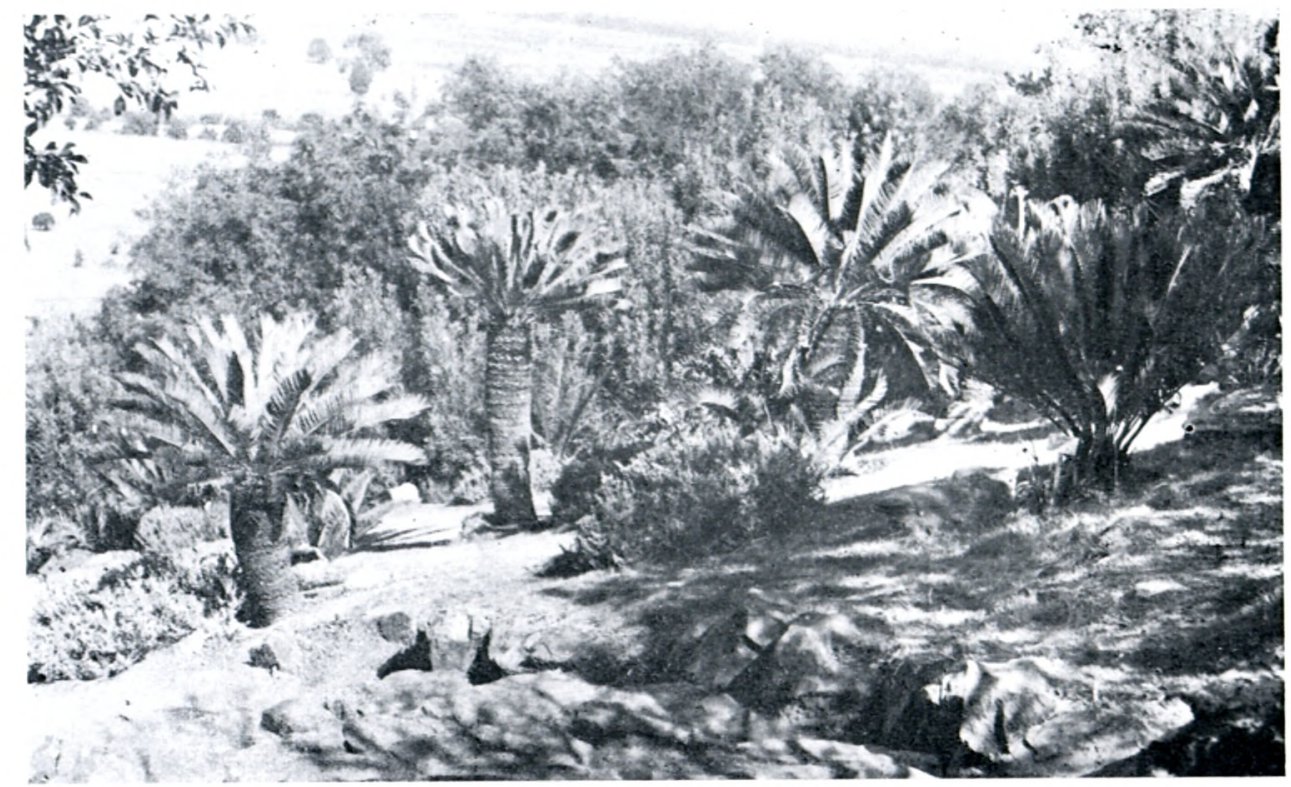

FIG. 3.--Portion of Cycad collection of Botanical Research Institute, Pretoria, started in 1950; photo taken 1965. 